University for Business and Technology in Kosovo

UBT Knowledge Center

UBT International Conference

2015 UBT International Conference

Nov 7th, 9:00 AM - 5:00 PM

\title{
Some Principles for Banks' Internal Control System in Albania
}

Artur Ribaj

Follow this and additional works at: https://knowledgecenter.ubt-uni.net/conference

Part of the Databases and Information Systems Commons, and the Information Security Commons

\section{Recommended Citation}

Ribaj, Artur, "Some Principles for Banks' Internal Control System in Albania" (2015). UBT International Conference. 115.

https://knowledgecenter.ubt-uni.net/conference/2015/all-events/115

This Event is brought to you for free and open access by the Publication and Journals at UBT Knowledge Center. It has been accepted for inclusion in UBT International Conference by an authorized administrator of UBT Knowledge Center. For more information, please contact knowledge.center@ubt-uni.net. 


\title{
Some Principles for Banks' Internal Control System in Albania
}

\author{
Artur Ribaj
}

\begin{abstract}
Internal control involves everything that controls risks to a bank. The objectives of internal control as a system relate to the reliability of financial reporting, timely feedback on the achievement of operational or strategic goals, and compliance with laws and regulations. The objectives of internal control at a specific transaction level refer to the actions taken to achieve the target within the allowed limit of risk. An effective internal control system reduces process variation, leading to more predictable outcomes. There are some important documents for regulating the internal control system as such: The Directive 2006/43/EC "On statutory audits of annual accounts and consolidated accounts", published by the European Commission in 2006; $8^{\text {th }}$ Company Law Directive of the European Union, Article 41; "The internal audit function in banks," Basel Committee on Banking Supervision, 2012; "Corporate Governance Principles for Banks" Basel Committee on Banking Supervision, 2015.

It should be noted that Albania, an EU candidate country, is approaching the EU directives and Basel principles via legislation and regulation framework. Related to bank's internal control system, its structure and responsibilities, Albania has taken periodically the way of accommodating the requirements of EU directives and Basel principles within the law no. 9662, dated 18.12.2006 "On Banks on the Republic of Albania", amended; regulation no. 63, dated 14.11.2012 and lately the new regulation, dated on 02.09.2015 “On Internal Control System". This last one, has given the minimum requirements for setting up an effective internal control system and supporting arrangements by the three lines of defence model; a strong internal control system, including an independent and effective internal audit functions, as part of sound corporate governance; the findings of internal audit to be followed and bank's management to take appropriate and timely corrective action in response to internal control weaknesses; the internal audit to provide vital assurance to bank's board of directors and supervisors with whom should be an enhanced two-way communication for discussing the risk areas identified, measures received, etc. This paper aims to inform bankers, researchers, and other stakeholders with some principles of internal control system regulated in Albania as well as raising some other related issues to be considerate for ensuring the efficiency and effectiveness of internal control system of banks in Albanian.
\end{abstract}

Keywords: internal control system; internal audit function; governance; lines of defence; risk management.

\section{Introduction}

Internal control has existed from ancient times. In Hellenistic Egypt there was a dual administration, with one set of bureaucrats charged with collecting taxes and another with supervising them. As defined in accounting and auditing is a process for assuring achievement of an organization's objectives in operational effectiveness and efficiency, reliable financial reporting, and compliance with laws, regulations and policies. Internal control involves everything that controls risks to a bank or its subsidiaries. The objectives of internal control as a system relate to the reliability of financial reporting, timely feedback on the achievement of operational or strategic goals, and compliance with laws and regulations. The objectives of internal control at a specific transaction level refer to the actions taken to achieve the target within the allowed limit of risk. An effective internal control system reduces process variation, leading to more predictable outcomes. Internal control is a key element of the Foreign Corrupt Practices Act (FCPA) of 1977 and the Sarbanes-Oxley Act of 2002, which required improvements in internal control in United States public corporations.

The Directive 2006/43/EC “On statutory audits of annual accounts and consolidated accounts", published by the European Commission in 2006, set audit committees on the path to becoming a key 
feature of the corporate governance framework of all EU Member States. The role of the audit committee, as required by the Directive, was broadly consistent with that set out in many longestablished corporate governance codes, namely to: ... monitor the effectiveness of the company's internal control and risk management systems; monitor the effectiveness of the company's internal audit function; etc.

According to 8th Company Law Directive of the European Union, Article 41 assigns a duty for monitoring the effectiveness of risk management and control systems by each "public-interest entity", which shall have an audit committee as well. Each respective State Authority shall determine the composition of audit committees being composed of non-board and board members of the audited entity. At least one member of the audit committee shall be independent and shall have competence in accounting and/or auditing. The definition of "public interest entity" varies across the EU, but generally one of them is considered the activity of banks [1].

On June 28, 2012, the Basel Committee on Banking Supervision (Basel Committee) issued revised supervisory guidance for assessing the effectiveness of internal audit functions in banks, entitled "The internal audit function in banks" replacing the 2001 document "Internal audit in banks and the supervisor's relationship with auditors", taking into account developments in supervisory practices and lessons from the last financial crisis, during which internal audit functions were criticized for their role in the failure to highlight weaknesses in overall risk management. The revised document specifically builds on the Basel Committee's "Principles for enhancing corporate governance", and presents 20 principles. These principles are agreed internationally by banking supervisors, following consultations with the banking sectors. Many of the above principles have also been addressed by other regulatory and/or association bodies, including but not limited to the United States Commodity Futures Trading Commission, the U.S. Dodd-Frank Act, and around 90\% of corporate governance codes of the EU member states recognize internal audit as an essential part of the corporate governance framework.

On July, 2015, the Basel Committee published "Corporate Governance Principles for Banks". The revised principles: expand the guidance on the role of the board of directors in overseeing the implementation of effective risk management systems; emphasize the importance of the board's collective competence as well as the obligation of individual board members to dedicate sufficient time to their mandates and to keep abreast of developments in banking; strengthen the guidance on risk governance, including the risk management roles played by business units, risk management teams, and internal audit and control functions (the three lines of defence), as well as underline the importance of a sound risk culture to drive risk management within a bank; provide guidance for bank supervisors in evaluating the processes used by banks to select board members and senior management; and recognize that compensation systems form a key component of the governance and incentive structure through which the board and senior management of a bank convey acceptable risktaking behavior and reinforce the bank's operating and risk culture.

It should be noted that Albania, an EU candidate country, is approaching the EU directives and Basel principles via legislation and regulation framework. Related to bank's internal control system, its structure and responsibilities, Albania has taken periodically the way of accommodating the requirements of EU directives and Basel principles within the law no. 9662, dated 18.12.2006 "On Banks on the Republic of Albania", amended; regulation no. 63 "On core management principles of banks and branches of foreign banks and criteria on the approval of their administrators", dated 14.11.2012 and lately the new regulation no. 67, dated on 02.09.2015 "On Internal Control System". This last one has given the requirements for setting up an effective internal control system and supporting arrangements by the three lines of defence model; a strong internal control system, including an independent and effective internal audit functions, as part of sound corporate governance; the findings of internal audit to be followed and bank's management to take appropriate and timely corrective action in response to internal control weaknesses; the internal audit to provide vital assurance to bank's board of directors and supervisors; etc.

\section{Some principals of internal control system regulated in Albania}

1. In addition to the article 37, point 2 of "Law on Banks" [2], the bank's board of directors has the ultimate responsibility for ensuring that executive management/bank's directorate/bank's senior management establishes and maintains an adequate, effective and efficient internal control system, 
supporting arrangements by the three lines of defence model, and, accordingly, the board should support the internal audit unit in discharging its duties effectively;

2. In addition to the article 45 and article 46 of "Law on Banks" [3], internal control system and internal audit unit should have independence, objectivity, professional competence and care in accordance with best practices and international standards of internal control;

3. The "Three lines of defence" model has to be essential for establishing clearly-structured corporate governance systems and should provide valid guidance on clear accountability for risk management and internal control. The "Three lines of Defence" structure is a valid conceptual definition of control levels: line controls, second-level monitoring controls and third-line independent assurance, but not to be interpreted as organizational reporting lines. Under the first line of defence, operational management has ownership, responsibility and accountability for assessing, controlling and mitigating risks. The second line of controls consists of activities covered by several components of internal governance (compliance, risk management, quality and other control departments). This line of defence monitors and facilitates the implementation of effective risk management practices by operational management and assists the risk owners in reporting adequate risk-related information up and down the bank. As the third line of defence, an independent internal audit function will, through a risk-based approach to its work, provide assurance to the bank's board of directors. This assurance encompasses all elements of a bank's risk management framework: from risk identification and assessment processes to the internal control system as a response to mitigating risks; this includes communication throughout the bank and to executive management, audit committee and the board of directors of risk-related information. The responsibility for internal control does not transfer from one line of defence to the next line;

4. In addition to other responsibilities as per regulation no.63 on 14.11.2012, the risk management unit and compliance unit, who are considered among the main units of the second line of defence should be responsible for overseeing the risk management and compliance risk management in view of the internal control system. These two units should have the adequate authority for accomplishing their functions;

5. Internal audit function or unit provides independent assurance to the board of directors and advises the executive management if it asked, on the quality and effectiveness of a bank's internal control, risk management and governance systems and processes, thereby helping the board and senior management protect the bank and its reputation;

6. In addition to the article 38, point 3 of "Law on Banks" [4], the audit committee should: oversee the bank's internal audit system; monitor the effectiveness of the internal audit unit; ensure that the internal audit unit carries out its responsibilities independently and on the basis of internal control standards; ensure that the bank's executive management has established and maintains an adequate and effective first and second line of defence; may propose the appointment or dismissal of the employees and head of internal audit unit; ensure a regular open dialogue between the external/statutory auditor, bank's executive management, supervisory authority and internal audit;

7. Each bank should have a permanent internal audit function that must be independent of the audited activities, which requires the internal audit function to have sufficient standing and authority within the bank, thereby enabling internal auditors to carry out their assignments with objectivity. Internal audit must have adequate resources available, supporting both efficient and effective audit planning and management. The internal audit function should be accountable to the board of directors, on all matters related to the performance of its mandate as described in the internal audit regulatory framework, which articulates as well the purpose, standing and authority of the internal audit function within the bank in a manner that promotes an effective internal audit function;

8. The completeness of the mandate of internal audit, the scope, budget and plan of auditing will be consulted from audit committee and then approved by the board of directors. In addition to other things, internal auditing should have full, free and unrestricted access to any function, activity or unit under review. Every bank activity (including the outsourced activities by the engagement of external experts to perform internal audit activities for supporting the internal audit function) or unit should fall within the overall scope of the internal audit function. The scope of the internal audit function's activities should ensure adequate coverage of matters within an annual internal audit plan, which can be part of a multi-year plan;

9. The determination of the frequency of inspection based on the assessment by a risk-based methodology for each field of activity and / or organizational units, to focus on those activities / organizational units that pose more risk by allocating human resources more efficiently; as well as 
extending the maximum cycle of 2 to 3 years for the checks carried out on those fields of activity and / or organizational units valued bank with low risk according to the risk-based methodology;

10. The board of directors to set an organizational unit responsible for tracking and reporting the level of implementation of the recommendations of the supervisory authorities, external/authorized auditors, control structures of the parent bank, etc.;

11. Every time, every issue raised by internal auditing for bank's executive management, as soon as possible should be reported in written to the bank's board of directors. The board of directors and audit committee should have meetings with head of internal audit unit or internal auditors without the presence of management.

12. In order the employees of internal audit unit to independently fulfill their responsibilities, the hiring, remuneration, and dismissal will be a decision reserved to the bank's board of directors, who might get recommendations from audit committee;

13. Integrity, professional competence, including the knowledge and experience of each internal auditor and of internal auditors collectively, is essential to the effectiveness of the bank's internal audit function. Internal auditors must act with integrity and professionalism;

14. The competency of the head of internal audit unit ("fit and proper"), requiring strong leadership capability as in addition to technical and communication skills; as well as the adequacy of resources, both human and technical, including diversity of professional competencies;

15. In addition to other responsibilities related to internal control system, the head of the internal audit unit should be responsible for ensuring that the internal auditors comply with sound auditing standards and with a relevant code of ethics which but must be adapted clearly to the legal and regulatory framework in Albania and bank's characteristics, activities and culture;

16. The enhanced two-way communication between the supervisory authority and the structures of internal control system. The frequencies of these meetings should be proportionate with the concept of proportionality, which mean the bank's size, the nature and risks of its operations and the complexity of its organization. They have to discuss the risk areas identified by both parties, measures received, etc.

18. Others...

\section{Conclusions}

1. The challenges arising from the economic situation, and changes in regulatory framework, increase the pressure for banks to adopt a robust governance framework keeping an effective communication between structures.

2. Risk management, internal control and audit functions provide reliable information channels for the bank's board of directors to monitor the effectiveness of risk management and internal control system. With regard to risk management, the bank's board and/or the audit committee needs to receive, at least yearly, a review of the bank's risks and its internal control system. They need to have appropriate information to know how the business model is impacted by major risks, and how value generation could be enhanced by opportunities or reduced by vulnerabilities of external environment or particular risks inherent to the activity of the bank and what strategies to be chosen for achieving the bank's mission.

3. Ultimately, the bank's board of directors assisted from audit committee has the final responsibility for internal control and reporting lines, accomplishing that, through delegation of duties, authorities, check and balance. Audit committee oversight must rely on an all-encompassing, comprehensive structure that incorporates all elements of corporate governance.

4. Independence of the audit is vital for the bank life. But, internal audit, external audit and audit committee are not truly independent because they are employed by the bank (the first one directly, the second and third under contract by bank's board of directors). The important feature about audit's independence for these three bodies is that it is independent of bank's executive management and can therefore give objective assurance to the bank's board of directors that has the ultimate responsibility and accountability for ensuring the efficiency and effectiveness of internal control system.

5. The critical issue facing the bank's board of directors and audit committee is the asymmetry of information reported to them. It might either overwhelm or disorient judgment of them. 


\section{Recommendations}

1. Rules are meaningless if the bank's culture is of non-compliance, for that fact, the board and executive management must set the "tone at the top" of the bank for a corporate culture, which acknowledges and maintains an effective control environment, where every person within the bank should be under monitoring by internal controls.

2. The bank's culture, code of conduct, human resources policies and performance reward systems are critical components of the internal control system. The culture of the bank should encourage individuals to report suspected breaches of law or regulations or other improprieties. Critical for this system to work is the protection of the people who "blow the whistle".

3. The regulation no. 63, dated 14.11.2012, needs further enhancement adoption with corporate governance principles for banks, published by Basel Committee on July, 2015 and recommendations of $8^{\text {th }}$ EU Company Law Directive, Article 41, for the composition of audit committee to be composed of non-board and board members of the bank with depth background in audit, and at least one member of the audit committee shall be independent.

4. The bank's board of directors and audit committee need to know the critical risk issues that require their attention and to state clearly what information need, its relevance, the format and timing of such information, for avoiding the asymmetry of information.

5. The bank's audit committee has to evaluate the reports from these multiple sources and advice the bank's board of directors to determine the direction the bank should take. Also, the audit committee has to ensure board of directors that executive management is taking necessary corrective actions within an appropriate time frame to address the findings, recommendations, control weaknesses, noncompliances with legal and regulatory framework and other problems identified by internal auditors, external auditors and supervisory authorities.

6. The audit committee has to have a charter that clearly sets out its role, responsibilities and accountabilities in providing internal control governance to effectively discharge the requirements delegated by the board of directors. The audit committee ongoing, but not less than three times per year, has to report to the board of directors on the status of the bank's internal control system.

7. The supervisory authorities has to enhance frequently the two-way periodic communication with bank's structures of internal control system discussing about risk areas identified by both parties, understanding the risk mitigation measures taken by the bank, monitoring the bank's response to weaknesses identified and supervising if bank management is too strongly influenced by rewards, such as bonus incentives, and the fear of shareholder demands to ignore or take risks that may lead to regulatory intervention or, even worse, financial failure.

8. Internal audit function should have the right to attend or observe executive committee meetings and to have timely access to relevant management information and committee materials.

9. Internal audit function should ensure that its internal audit reports are provided to the board of directors or the audit committee without bank's executive management filtering.

10. Banks in Albanian, have to comply as a minimum with the requirements of law no. 9662, dated 18.12.2006 "On Banks on the Republic of Albania", amended; the regulation no.63, dated 14.11.2012 "On core management principles of banks and branches of foreign banks and criteria on the approval of their administrators"; and the Regulation no. 67, dated 02, 2015 "On Internal Control System", and furthermore illuminating their internal regulatory acts with other Basel-based principles governing effectiveness, scope and governance.

\section{References:}

1. Law no. 9662, dated 18.12.2006 "On Banks on the Republic of Albania", amended. Respectively: Article 37 "Powers of the Supervisory/Steering Council/Board", Point 2; Article 38 "Control Committee"; Article 45 "Internal control system"; Article 46 "Internal control unit"; Article 47 "Financial reports", Point 3; Article 49 "Audit from the statutory/external auditor", point 3; Article 63 "Large exposures", point 3; Article 76 "Order 
for the abatement of the unlawful acts", point 1; Article 80 "Serious breaches", Point 1; Article 88 "Submission of Data", Point 1; Article 89 "Penalizing measures", Point 3.

2. Regulation "On the Internal Control System" approved by SC of BoA with decision no.67 on 02 September 2015;

3. Regulation no. 63, dated 14.11.2012 "On core management principles of banks and branches of foreign banks and criteria on the approval of their administrators"

4. "The internal audit function in banks," Basel Committee on Banking Supervision, 2012;

5. "Internal audit in banks and the supervisor's relationship with auditors," Basel Committee on Banking Supervision, 2001;

6. "Principles for enhancing corporate governance," Basel Committee on Banking Supervision, 2010

7. $8^{\text {th }}$ Company Law Directive of the European Union

8. Corporate Governance Principles for Banks, published by Basel Committee on July, 2015

9. Directive 2006/43/EC "On statutory audits of annual accounts and consolidated accounts", published by the European Commission in 2006

10. Publications on: Policy position paper on risk management and internal audit; and briefing on whistleblowing

11. Publications of CIA-Certified Internal Auditor, CIIA - Chartered Internal Auditor, CFSACertified Financial Services Auditor, CGAP-Certified Government Auditor, CCSACertified, Control Self-Assessment, CRMA-Certified Risk Management Auditor and COSO-Committee of Sponsoring Organizations of the Tread way Commission.

\section{Citations}

[1] The EC 8th Company Law Directive defines a public interest entity as: “...entities governed by the law of a Member State whose transferable securities are admitted to trading on a regulated market of any Member State within the meaning of Article ..., credit institutions within the meaning of Article ... and insurance undertakings as defined in Article .... Member States may also designate other entities as public interest entities, for instance entities that are of significant public relevance because of the nature of their business, their size or the number of their employees..."

[2] The article 37, point 2 of "Law on Banks": “...The main responsibilities of the Steering Council shall include amongst others:...taking the necessary and adequate measures for ensuring the integrity of the financial and accounting system of the bank, including the independent controlling of the bank, and ensuring the existence of the appropriate systems of control especially with regard to risk management, operational and financial system of the bank, as well as ensuring compliance with the law and best practices in the banking system; monitoring and supervising implementation of legal and regulatory requirements and of the best practices in banking system;...'

[3] The article 45 of "Law on Banks": “...bank shall organize an internal control system for the purposes of monitoring the implementation of internal policies and procedures, evaluation of effectiveness of banking activity and monitoring compliance with law and by-laws; to identify the exposure of the bank to the type of risks, as well as measuring, administering and monitoring their levels;...", and the article 46 of "Law on Banks": "...internal control unit, as part of the internal control system with the responsibility for the provision of an effective control over the implementation of policies, regulations and procedures approved by the bank's board of directors, as well as provision of accuracy of information and effectiveness of measures preventing risks faced by the bank..."

[4] The article 38, point 3 of "Law on Banks": “...controls and supervises accounting procedures and internal control of the bank, including the procedures defined by the Bank of Albania, and supervises the implementation of these procedures as well as controls the bank accounts and respective registrations; considers internal control reports and monitors the way conclusions from such reports are dealt with; proposes the external auditor and realizes the communication between him and the internal control of the bank; evaluates the financial situation of the bank based on the report of the external auditor; controls compliance of the activity of the bank with laws and by-laws and notifies the Steering Council of the bank about the conclusions; gives an opinion to the Steering Council of the bank in relation to issues, for which the latter has requested such an opinion; approves the financial reports and statements prepared by the bank and which the bank intends to publish;..." 